\title{
The Study of Tree Species Diversity in Dry Forest of East Nusa Tenggara, Indonesia
}

\author{
Aah Ahmad Almulqu 1,2, ${ }^{\text {, }}$ Noulkamol Arpornpong ${ }^{3}$ and Jaruntorn Boonyanuphap ${ }^{3}$
}

\begin{abstract}
We examined structure, diversity and importance value index (IVI) of tree species in dry forests of Binafun, Bonmuti, Letkole and Oelbanu, Mutis Timau Conservation Forest Management Unit, East Nusa Tenggara province, Indonesia. To obtain data on the composition and diversity of vegetation carried out through the analysis of tree species using sampling plots in a rectangular shape, with a size of $100 \mathrm{~m} \times 100 \mathrm{~m}$ at $100 \mathrm{~m}$ intervals. Results of tree species list showed that there were 94 species belong to 45 families and 72 genera. Tree species richness ranged from 1.81 to 10.06 , tree density about 166 individual/ha-545 individuals/ha and basal area ranged from $5.78 \quad \mathrm{~m}^{2} / \mathrm{ha}$ to $27.79 \quad \mathrm{~m}^{2} / \mathrm{ha}$. Eucalyptus urophylla was the most abundant tree in the research sites (except Letkole) and well distributed. Species richness, density, Shannon-Wiener index and basal area are important factors in determining the tree species diversity in research sites. The results in this research should be useful to the dry forest management and conservation managers and researchers.
\end{abstract}

Keywords: Structure, diversity, importance value index, Mutis Timau Conservation Forest Management Unit, basal area.

\section{INTRODUCTION}

Tropical forests provide many ecosystem services such as species conservation, prevention of soil erosion, and preservation of habitat for plants and animals (Armenteras et al., 2009). Trees, an important component of vegetation, must therefore be constantly monitored and managed in order to direct successional processes towards maintaining species and habitat diversity (Attua and Pabi, 2013) and it's also fundamental to tropical forest biodiversity (Evariste et al., 2010). Biodiversity is essential for human survival and economic well being and for the ecosystem function and stability (Singh, 2002). According to Noss (1990), biodiversity is not simply the number of different genes, species, ecosystems, or any other group of things in a defined area. The composition, structure and function determine and also constitute the biodiversity of an area. Knowing species diversity is a useful tool in plant ecology and forestry to compare the composition of different species. Tree species diversity in tropical forests differ greatly from location to location mainly due to variation in biogeography, habitat, and disturbance (Neumann and Starlinger, 2001). Characterization of the structure and species composition of tree communities is the first step in understanding forest ecology and dynamics. For example, such information has been useful for comparing and understanding historical and ecological relationships among forests (Ashton et al., 2004). The analysis of tree community structure and diversity is still challenging for researchers in tropical ecology (Bawa et al., 2004), because tropical forests are the richest biological communities on earth and these forests have been recognized to harbor a significant proportion of global biodiversity (Myers et al., 2000).

Prior to forest management operations, biodiversity inventories are used to determine the nature and distribution of biodiversity resources of the region being managed. Such biodiversity inventories are best integrated with the timber resource inventories in order that forest management operations can be planned (Rennolls and Laumonier, 2000). The rapid inventory of tree species that provides information on diversity will represent an important tool to enhance our ability to maximize biodiversity conservation (Baraloto et al., 2013) and will help us to understand the patterns of tree species composition and diversity. Understanding tree composition and structure of forest is a vital instrument in assessing the sustainability of the forest, species conservation, and management of forest ecosystems (Kacholi, 2014).

Here, we present the first study on composition and structure of tree species communities in dry forest of East Nusa Tenggara, Indonesia. The present study is significant in producing useful baseline data in order to conserve, manage, valuable data of dry forest assessment and improve our knowledge in identification of ecologically useful tree species of dry forest in Indonesia. The objective of this study was to compared composition and diversity of tree species and quantified the importance value index of tree species, diversity

${ }^{1}$ Graduate School of Naresuan University, University of Naresuan,

Phitsanulok 65000, Thailand

${ }^{2}$ Forest Management Study Program, Kupang State Agricultural Polytechnic,

(Politani Kupang) Kupang, East Nusa Tenggara 85011, Indonesia

${ }^{3}$ Faculty of Agriculture, Natural Resources and Environment,

Naresuan University,Phitsanulok 65000, Thailand

Received October 10,2017, Accepted November17, 2017 
index and tree species distribution in the tropical dry forest of Binafun, Bonmuti, Letkole and Oelbanu, Mutis Timau Conservation Forest Management Unit, East Nusa Tenggara province, Indonesia.

\section{MATERIALS AND METHODS}

The study was carried out at the Mutis Timau Conservation Forest Management Unit, which is covered on Kupang regency, Timor Tengah Selatan regency and Timor Tengah Utara regency (Lat. 90 20' $00 "$ - 9045 ' 10" South and long. 123042'30" - 1240 20'00" E) in eastern Indonesia (Fig.1).

The research sites represents the dry forests of East Nusa Tenggara, Indonesia, and surrounding areas are the wettest areas on the island of Timor, the rain fell almost every month with the highest frequency of rainfall occurs during November to July, temperatures range between $14^{\circ} \mathrm{C}-29^{\circ} \mathrm{C}$, and in extreme conditions can decrease up to $9^{\circ} \mathrm{C}$. High-speed high winds occurred in November until March. About $71 \%$ area are hilly (15-30\% slope) to mountainous (>30\% slope) (Mulyani et al., 2013). The high-intensity rainfall (2 000-3 $000 \mathrm{~mm} / \mathrm{year}$ ) during the rainy season (Fisher et al., 1999).

The study area was divided into four study sites i.e. Binafun dry forest area, Bonmuti dry forest area, Letkole dry forest area and Oelbanu dry forest area for studying the status of plant diversity and community structures species of the study sites. To obtain data on the composition and diversity of vegetation carried out through the analysis of vegetation using sampling plots in a rectangular shape, with a size of $100 \mathrm{~m}$ x $100 \mathrm{~m}$ at $100 \mathrm{~m}$ intervals. The replications of plot in four study sites were 2 plots. In each plot, all tree species were measured for species name, height, and diameter at breast height $(\mathrm{DBH}) \geq 20 \mathrm{~cm}$ (1.3 meters). Morphologically, specimen identifications were confirmed with the collection of Herbarium at Kupang Forestry Research Agency, Ministry of Forestry, East Nusa Tenggara, Indonesia.

The species richness and total species richness were calculated as the number of species per plot and the total species number at each site, respectively. The density of a species was the number of trees of that species per hectare. The relative density of a species was calculated as its density divided by the total density of all species and multiplied by 100 . The frequency of a species was the number of plots in which that species was found. The relative frequency of a species was calculated as the frequency of a species divided by the total number of sampling plots and multiplied by 100 (Koonkhunthod et al., 2007).

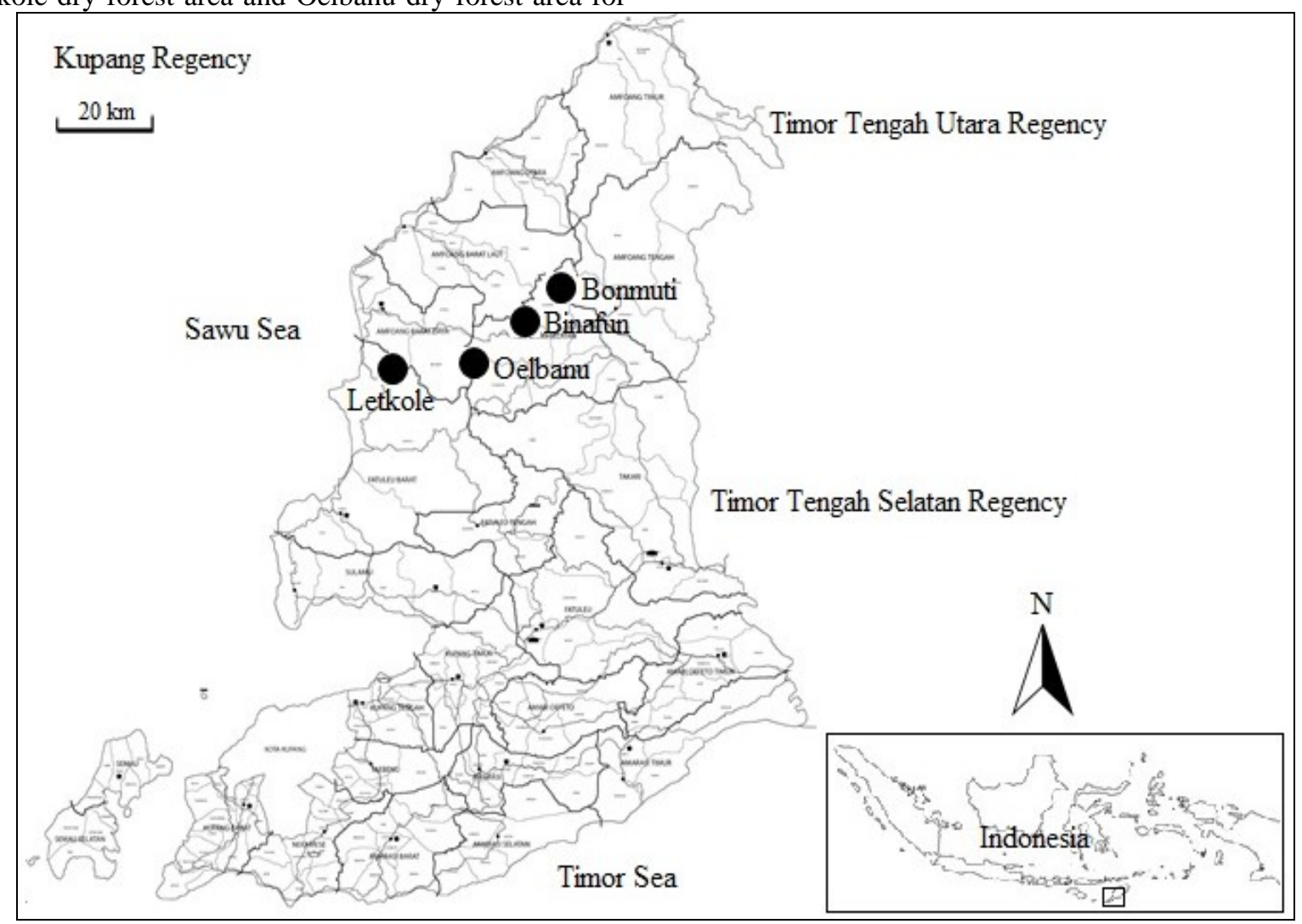

Fig. 1. Map of research sites 
The Importance value Index (IVI) for a species is a composite of three ecological parameters including density, frequency and basal area, which measure different features and characteristics of a species in its habitat (Soerianegara and Indrawan, 1988). Basal area per tree is the cross-sectional area of a tree at breast height. It was calculated from diameter at breast height. Ecologically, density and frequency of a species measure the distribution of a species within the population while basal area measures the area occupied by the stems of trees. Diversity of trees at each site was estimated by the Shannon-Wiener index = H' (Shannon, 1948). The Shannon diversity index computed as:

$$
\mathrm{H}^{\prime}=\sum_{\mathrm{i}=1}^{\mathrm{s}}\left(\frac{\mathrm{ni}}{\mathrm{N}}\right) \ln \left(\frac{\mathrm{ni}}{\mathrm{N}}\right)
$$

Where, $\mathrm{N}=$ number species and $\mathrm{ni}=$ number of individuals in a species in sample quadrats. And Principal Components Analysis (PCA) was used to summarize the relationship of tree species structure parameters for all sites by using XLStat 2014 software.

\section{RERSULTS AND DISCUSSION}

Based on the research, a total of 2097 individuals belonging to 94 species among 72 genera and 45 families from eight 1-ha plots were enumerated in the research sites. In the present research, species richness in the research sites showed a wide variation, ranging from a low value of 1.81 in plot 1 of Oelbanu, to a very high 10.06 in plot 2 of Letkole. The highest stand density was observed in plot 2 of Oelbanu (545 individuals/ha), whereas the lowest stand density was observed in plot 1 of Oelbanu (166 individual/ha). The Table 1. Characteristics of tree species in the research sites

\begin{tabular}{ccccc}
\hline Research sites & Species richness & Density & Basal area & Shannon-Wiener index \\
\hline Binafun & & & & 3.3 \\
Plot 1 & 8.18 & 352 & 27.79 & 3.2 \\
Plot 2 & 7.81 & 219 & 27.27 & 3.25 \\
Average & 7.99 & 285.5 & 27.53 & 3.24 \\
Bonmuti & & & & 3.28 \\
Plot 1 & 4.56 & 273 & 18.81 & 3.26 \\
Plot 2 & 4.75 & 225 & 5.78 & 3.8 \\
Average & 4.65 & 249 & 12.295 & 3.9 \\
Letkole & & & & 3.85 \\
Plot 1 & 9.93 & 515 & 18.27 & 1.5 \\
Plot 2 & 10.06 & 534 & 24 & 3.07 \\
Average & 9.99 & 524.5 & 21.135 & 2.28 \\
Oelbanu & & & & 18.49 \\
Plot 1 & 1.81 & 166 & 19.37 & 18.93 \\
Avet 2 & 8.06 & 545 & & \\
\hline
\end{tabular}

basal area in all the study plots ranged from $5.78 \mathrm{~m}^{2} / \mathrm{ha}$ (plot 2 of Bonmuti) to $27.79 \mathrm{~m}^{2} /$ ha (plot 1 of Binafun) and the mean basal area for the each sites was 27.53 $\mathrm{m}^{2} / \mathrm{ha}, 12.295 \mathrm{~m}^{2} / \mathrm{ha}, 21.135 \mathrm{~m}^{2} /$ ha and $18.93 \mathrm{~m}^{2} /$ ha for Binafun, Bonmuti, Letkole and Oelbanu, respectively (Table 1). These data contribute to dry forest structure in the research sites. According to Ingram et al., (2005), in Madagascar, the low basal area values in the forests were related to high accessibility by the nearby community and lack of enough protection, which could account for observed values too. Generally, in many dry forest, lower basal area is mainly characterized by high abundance of young trees (Pardiniet al., 2005).

Diversity of tree species in the study plots calculated using the ShannoneWeiner index $\left(\mathrm{H}^{\prime}\right)$ showed that the highest diversity was in plot 2 Letkole (3.9) and the lowest diversity was in plot 1 Oelbanu (1.5), ranged between 0.81 and 4.1 (Sundarapandian and Swamy, 2000). Species diversity was significantly influenced by forest structure and species composition (Huang et al., 2003). Knowing species diversity is a useful tool in plant ecology and forestry to compare the composition of different species. Tree species diversity in tropical forests differ greatly from location to location mainly due to variation in biogeography, habitat, and disturbance (Neumann and Starlinger., 2001). Biodiversity indices are generated to bring the diversity and abundance of species in different habitats to a similar scale for comparison and the higher the value, the greater the species richness. The higher values of the diversity indices revealed a forest with high tree species diversity and abundance (Adekunle et al., 2013). 
The five most highest rank of density was measured for all research sites (Fig. 2). Totally, Eucalyptus urophylla had the highest density of $68.83 \%, 57.67 \%$ and $43.99 \%$ in Binafun, Bonmuti and Oelbanu, respectively. Also Ficus ampelos in Letkole (13.35\%). Generally, E. urophylla has highest density than others species, because the nature surrounding mount Mutis Timau Conservation Forest Management Unit is considered to be one of the few remaining pure stands of E. urophylla in Indonesia (Robinson and Supriadi, 1981) and the species has no major edaphic requirements, it is appropriate for reforestation, both in flooded soils and in dry soils of low tropical lands. $E$. urophylla occurs in open, often secondary, mountain forest and performs best on deep, moist, well-drained soils. It grows in the vegetal formations of dry deciduous forest and moist evergreen forest (Pepe et al., 2004).

In the present study, the value of important index (IVI) for tree species (Table 2) in the Binafun suggested that Elattostachys verrucosa (151.64), E. urophylla (79.13), and Prunus sp (65.71) were the dominant species. These species were followed by Zizyphus timoriensis (60.36) and Celtis wightii (59.34). However, among the site of Bonmuti, Phaleria laurifolia (105.31), E. urophylla (103.78), and Hibiscus timoriensis (89.81) were the dominant species, followed by Elattostachys verrucosa (79.83), and Celtis cinnamomea (79.79). In the site of Letkole, Aglaia heptandra (98.44), Melaleuca leucadendron (87.9), and Drypetes macrophylla (82.52) were the dominant species with the highest IVI values, followed by Wikstroemia androsaemifolia (60.97) and Celtis cinnamomea (56.19). Where as in site of Oelbanu, Ceriops tagal (188.28), Dryobalanops aromatic (159.09), and E. urophylla (126.2) were the dominant species followed by Schleichera oleosa (77.76), and Vitex parviflora (51.21) were the codominant species. These high value of IVI is largely due to its higher relative frequency, density, and dominance compared to other species.

The presence of many species with lower IVI values at Binafun (Canarium asperum=2.89, Podocarpus amara=3.26, Ficus glomerata=3.41, Cordia $s p p=5.04$ ), Bonmuti (Aglaia heptandra=5.35, Ficus ampelos $=6.68$, Gyrocarpus americanus $=8.54, \quad$ Ficus callosa $=8.75)$, Letkole (Albizzia procera $=1.82, \quad$ Kleinhovia hospital=2.04, Ficus benjamina=2.06, Cudrania cochinchinensis=2.08) and Oelbanu (Viburnum $s p=4.25, \quad$ Syzygium javanica $=7.75, \quad$ Terminalia catappa $=9.36$, Ficus benjamina=9.39) are indication that the majority of species are rare in the research sites, its may causedby competition within the dry forest

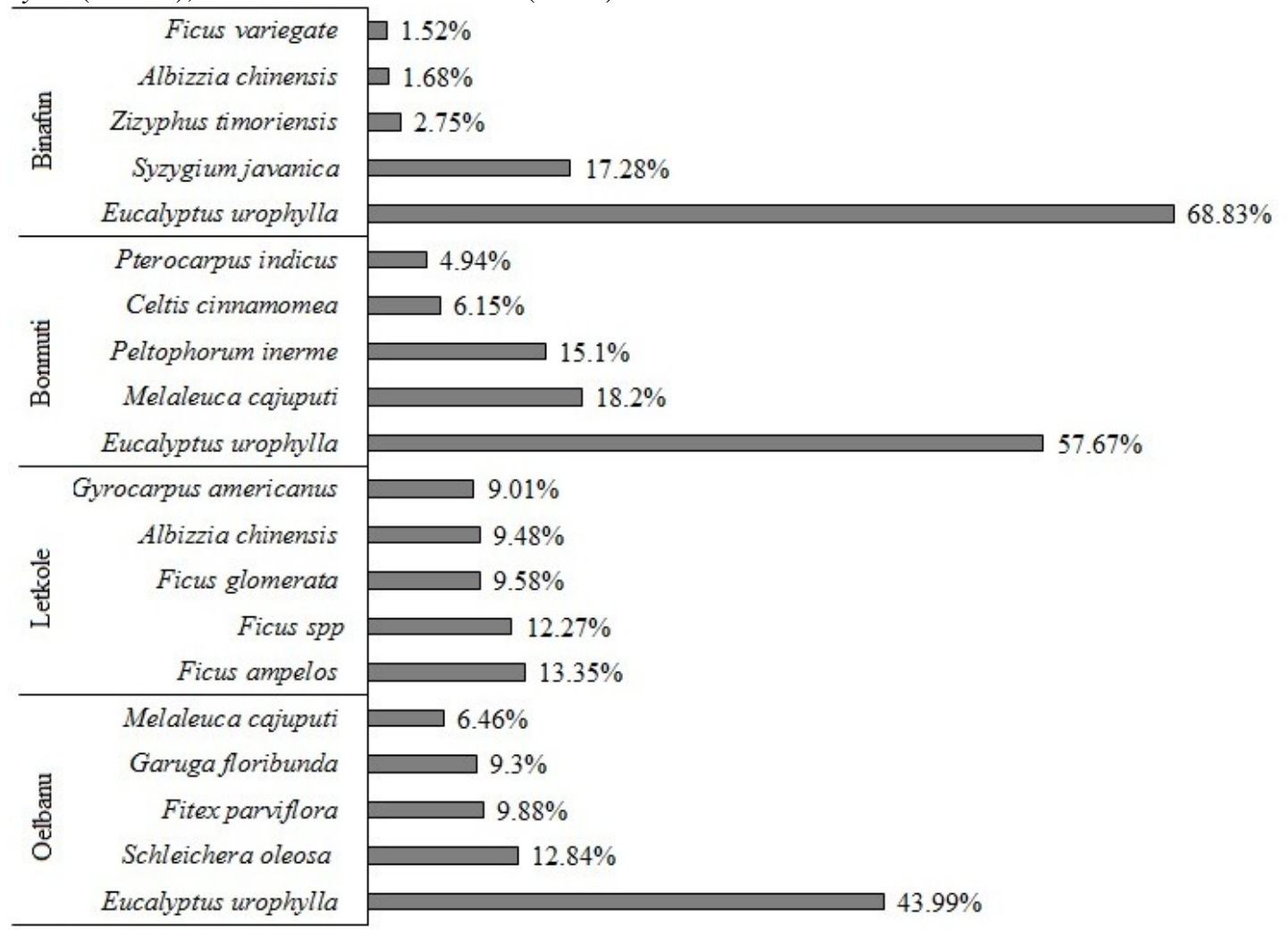

Fig. 2. The most common tree species in the research sites (\%) 
Table 2. The important value index (IVI) of tree speciesin the research sites

\begin{tabular}{|c|c|c|c|c|c|}
\hline \multirow{2}{*}{ Scientific name } & \multirow{2}{*}{ Family } & \multicolumn{4}{|c|}{ IVI } \\
\hline & & Binafun & Bonmuti & Letkole & Oelbanu \\
\hline Acacia oraria & Mimosaceae & & & 3.56 & \\
\hline Aglaia heptandra & Meliaceae & & 5.35 & 98.44 & \\
\hline Albizzia chinensis & Fabaceae & 16.35 & 38.69 & 11.64 & \\
\hline Albizzia lebekioides & Fabaceae & & & 2.8 & \\
\hline Albizzia procera & Fabaceae & & & 1.82 & \\
\hline Albizzia saponaria & Fabaceae & & & 2.47 & \\
\hline Alstonia scholaris & Apocynaceae & & & 17.05 & 17.38 \\
\hline Alstonia villosa & Apocynaceae & 42.17 & & & \\
\hline Bambusa spinosa & Poaceae & & & & 24.38 \\
\hline Bauhinia malabarica & Leguminosae & & & 4.45 & \\
\hline Broussonetia papyrifera & Moraceae & & & 4.19 & \\
\hline Canarium asperum & Burseraceae & 2.89 & 12.04 & & \\
\hline Casuarina junghuhniana & Casuarinaceae & & & & 28.91 \\
\hline Celtis cinnamomea & Ulmaceae & 17.13 & 79.79 & 56.19 & \\
\hline Celtis wightii & Ulmaceae & 59.34 & & 14.05 & \\
\hline Ceriops tagal & Rhizophoraceae & & & & 188.28 \\
\hline Cordia spp & Boraginaceae & 5.04 & & 3.96 & 20.81 \\
\hline Cudrania cochinchinensis & Moraceae & & & 2.08 & \\
\hline Desmodium cephalotis & Cephalotaceae & 6.043 & & & \\
\hline Dryobalanops aromatica & Dipterocarpaceae & & & & 159.09 \\
\hline Drypetes longifolia & Putranjivaceae & & & 6.83 & \\
\hline Drypetes macrophylla & Putranjivaceae & & & 82.52 & \\
\hline Dysoxylum gaudichaudianum & Meliaceae & 49.98 & & 55.31 & \\
\hline Elattostachys verrucosa & Sapindaceae & 151.64 & 79.83 & 4.17 & \\
\hline Eleocarpus peyiolatus & Elaeocarpaceae & 17.73 & 15.19 & & \\
\hline Eucalyptus urophylla & Myrtaceae & 79.13 & 103.78 & & 126.2 \\
\hline Eugenia littorale & Myrtaceae & & 51.18 & 2.97 & \\
\hline Eugenia polyantha & Myrtaceae & & & 4.01 & \\
\hline Euodia macrophylla & Rutaceae & 23.56 & 56.48 & & \\
\hline Exocarpus latifolia & Santalaceae & & & 3.65 & \\
\hline Ficus ampelos & Moraceae & 12.88 & 6.68 & 43.7 & \\
\hline Ficus benjamina & Moraceae & & & 2.06 & 9.39 \\
\hline Ficus callosa & Moraceae & 5.85 & 8.75 & & \\
\hline Ficus flaveola & Moraceae & & 31.83 & & \\
\hline Ficus fulva & Moraceae & 8.994 & & & 10.28 \\
\hline Ficus gibbosa & Moraceae & & & 10.5 & \\
\hline Ficus glomerata & Moraceae & 3.41 & & 24.39 & 46.58 \\
\hline Ficus hispida & Moraceae & & & 11.63 & \\
\hline Ficus nervosa & Moraceae & & 12.76 & & \\
\hline Ficus racemosa & Moraceae & & & 5.11 & \\
\hline Ficus spp & Moraceae & 10.5 & & 36.61 & \\
\hline Ficus variegata & Moraceae & 14.05 & 61.57 & 7.27 & \\
\hline Garuga floribunda & Burseraceae & & & 6.73 & 24.73 \\
\hline Gnetum gnemon & Gnetaceae & & & 9.07 & \\
\hline Gyrocarpus americanus & Hernandiaceae & 10.56 & 8.54 & 30.81 & 25.49 \\
\hline Harissonia perforata & Simaroubaceae & 7.53 & & & \\
\hline Hibiscus tiliaceus & Malvaceae & & & & 16.32 \\
\hline
\end{tabular}


Continue Table 2.

\begin{tabular}{|c|c|c|c|c|c|}
\hline \multirow{2}{*}{ Scientific name } & \multirow{2}{*}{ Family } & \multicolumn{4}{|c|}{ IVI } \\
\hline & & Binafun & Bonmuti & Letkole & Oelbanu \\
\hline Hibiscus timoriensis & Malvaceae & & 89.81 & & \\
\hline Homalium tomantosum & Salicaceae & & & 4.12 & \\
\hline Hymenodictyon excelsum & Rubiaceae & & & 4.25 & \\
\hline Jambolifera trifoliata & Rutaceae & & & & 13.16 \\
\hline Kleinhovia hospita & Malvaceae & & & 2.04 & \\
\hline Lagerstroemia $s p$ & Lythraceae & & 64.17 & 4.66 & \\
\hline Lantana camara & Verbenaceae & & & 8.79 & \\
\hline Leea sp. & Vitaceae & & & 19.46 & \\
\hline Litsea diversifolia & Lauraceae & & & 5.46 & 19.57 \\
\hline Macaranga tanarius & Euphorbiaceae & 16.2 & & 9.23 & \\
\hline Maesa latifolia & Primulaceae & & & 9.71 & \\
\hline Mallotus philippinensis & Euphorbiaceae & & & 7.38 & \\
\hline Mangifera indica & Anacardiaceae & & & & 10.97 \\
\hline Melaleuca cajuputi & Myrtaceae & & 55.64 & & 12.22 \\
\hline Melaleuca leucadendron & Myrtaceae & 14.24 & & 87.9 & \\
\hline Mischocarphus sundaicus & Sapindaceae & & & 18.33 & \\
\hline Nauclea orientalis & Rubiaceae & & & 14.5 & \\
\hline Nephelium juglandifolium & Sapindaceae & & & 5.26 & \\
\hline Omalanthus populneus & Euphorbiaceae & 16.36 & & & \\
\hline Oroxylum indicum & Bignoniaceae & & & 8.74 & \\
\hline Peltophorum inerma & Fabaceae & & & 15.07 & 19.91 \\
\hline Phaleria laurifolia & Thymelaeaceae & 45.7 & 105.31 & 12.65 & \\
\hline Photinia sp & Rosaceae & & & 17.85 & \\
\hline Phyllanthus sp. & Phyllanthaceae & & & 12.82 & \\
\hline Pipturus argenteus & Urticaceae & 18 & & & \\
\hline Pittosporum timorense & Pittosporaceae & & & & 20.67 \\
\hline Podocarpus amara & Podocarpaceae & 3.26 & & & \\
\hline Podocarpus imbricata & Podocarpaceae & 23.4 & & & \\
\hline Polyscias rumphiana & Araliaceae & & & 2.1 & \\
\hline Prunus $s p$ & Rosaceae & 65.71 & & 4.16 & \\
\hline Pterocarpus indicus & Fabaceae & & 18.14 & & \\
\hline Pterocymium tinetorium & Malvaceae & & & 12.21 & \\
\hline Pygeum parviflorum & Rosaceae & & & 6.65 & \\
\hline Schleichera oleosa & Sapindaceae & & & 8.91 & 77.76 \\
\hline Sesbania grandiflora & Fabaceae & 17.38 & 23.06 & & \\
\hline Sterculia foetida & Sterculiaceae & & & 14.2 & \\
\hline Syzygium javanica & Myrtaceae & 48.1 & & & 7.75 \\
\hline Tamarindus indica & Fabaceae & & & & 20.54 \\
\hline Tarenna pubiflora & Rubiaceae & & & 15.65 & \\
\hline Terminalia catappa & Combretaceae & & & 13.46 & 9.36 \\
\hline Terminalia mollis & Combretaceae & 34 & & 2.14 & \\
\hline Timonius sericaus & Rubiaceae & & & 3.89 & 11.92 \\
\hline Viburnum $s p$ & Adoxaceae & 41.92 & 26.36 & & 4.25 \\
\hline Vitex parviflora & Verbenaceae & & & & 51.21 \\
\hline Wikstroemia androsaemifolia & Thymelaeaceae & & & 60.97 & \\
\hline Wrightia calycina & Apocynaceae & & & 10.39 & \\
\hline Zizyphus timoriensis & Rhamnaceae & 60.36 & 44.98 & 6.68 & 20.68 \\
\hline
\end{tabular}


poor dispersability of tree species, natural or anthropogenic disturbance and existence of a resource gradient, which causes species to occupy different positions within it resulting in abundance distribution variation (Schwarz et al., 2003).

The PCA ordination of the eight plots on the basis of species basal cover is presented in Figure 3. The PCA axis 1 accounted for $66.13 \%$ variation in species composition while PCA axis 2 accounted for $23.64 \%$ variation. The PCA axis 1 was related with species richness (SR), density (Dens), Shannon-Wiener index $\left(\mathrm{H}^{\prime}\right)$ and the PCA axis 2 represented the basal area (BA). This significant relationships area indicated that parametersare important in determining the diversity of the dry forest communities in research areas, particularly at plot 1 of Letkole (H'), plot 2 of Oelbanu (density and species richness), plot 2 of Letkole (species richness) and plot 1 of Binafun (basal area).

According to Orth and Colette (1996), the H' index has strong values for species with recoveries of same importance and it takes low values, when some species have strong recoveries. Our study showed that plot 1 of Letkole has a high value of H' index (3.8), its mean the existence of variability of biodiversity in the study site. Low diversity index in plot 1 of Oelbanu (1.5) could be explained by the fact that it is dominated by a single species E. urophylla. This species contributes nearly

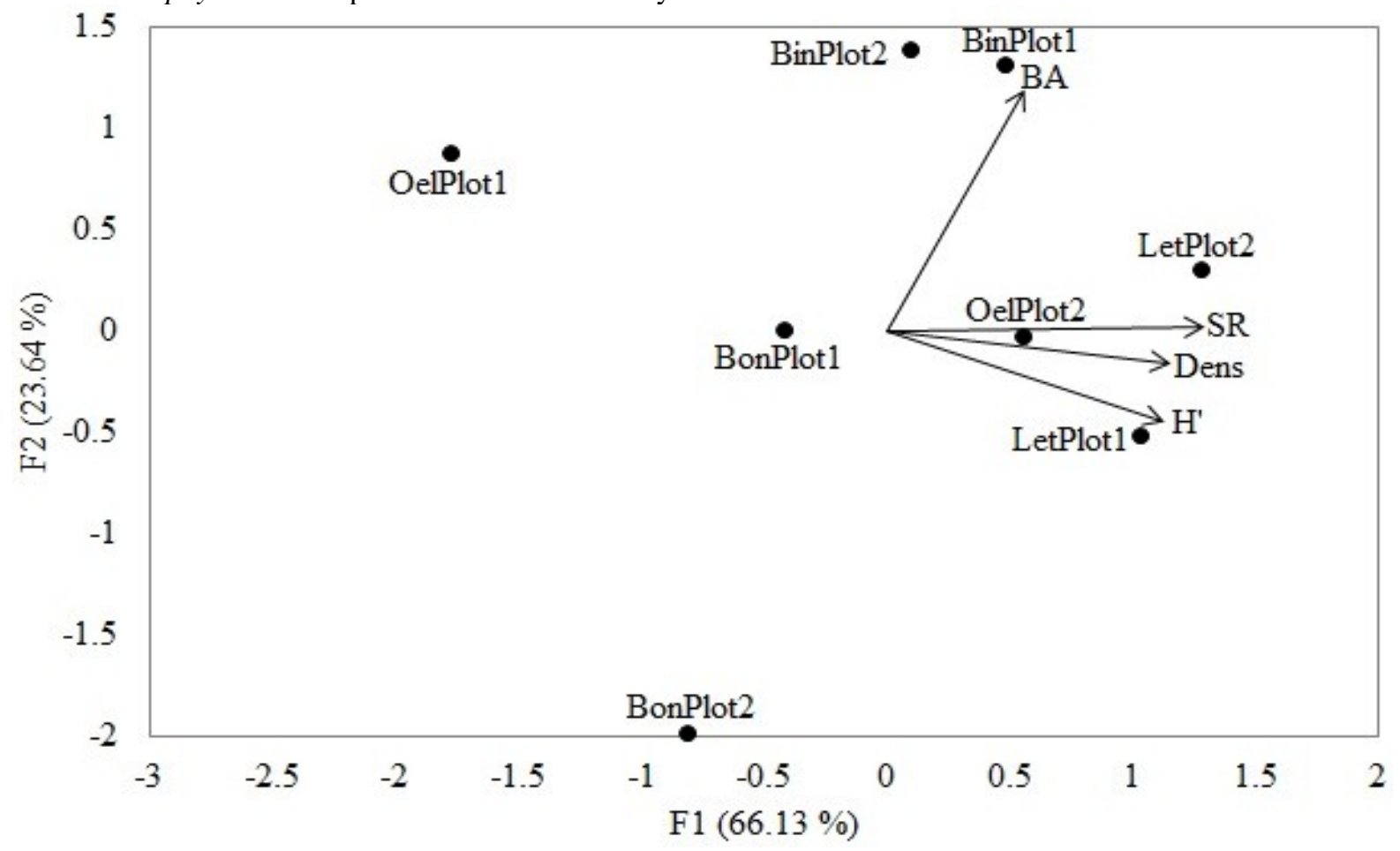

$43.99 \%$ of the total number of trees in the plot. Regarding heterogeneity,many authors think that the structural heterogeneity of the forests and their high species richness are often interpreted in terms of forest dynamics and relationship with the resulting phenomena of succession (Trichon, 1997).

Species richness is a regional attribute (Wagner et al., 2014), in the sense that species are produced mostly by the evolutionary divergence of populations in isolation, which requires spatial heterogeneity on scales sufficient to reduce gene flow for long periods (Ricklefs, 2015).

Moreover, mechanisms by which species richness within a region feeds back on the rate of species production within that region have, as yet, received little attention. One possibility is that increasing species richness intensifies interspecific competition and limits the number of species that can coexist locally, thereby restricting immigration from outside the region or preventing allopatric sister species produced within a region from achieving secondary sympatry (Pigot and Tobias, 2013). Recent studies have demonstrated a strong relationship between total species richness and temperature, precipitation, and net primary productivity (Hawkins et al., 2003), e.g., in South Africa (Sanders et al., 2007), Tanzania (Karger et al., 2011), and India (Sharma et al., 2009).

Fig. 3. PCA for tree species richness (SR), density (Dens), Shannon-Wiener index (H') and basal area (BA) in the research sites 
However, in the present study of Silva-Flores et al., (2014) at Mexico, the relationship between diversity and temperatures in degrees Celsius was almost negative and nonlinear, its may caused by significant heterogeneity in slopes among data sets and the combination of slopes across studies were significantly lower than the range of slopes prediction (Hawkins $e t$ al., 2007).

\section{CONCLUSION}

It could be concluded that E. urophylla were very abundant in the research sites (except Letkole) and were widely distributed. The lowest distribution of of Albizzia procera, Kleinhovia hospital, Ficus benjamina and Cudrania cochinchinensis in Letkole were scarcely caught in the research period. However, there is no single dominance tree species in Letkole. Species richness, density, Shannon-Wiener index and basal area important in determining the tree species diversity in research sites. The results of research in this research should be useful to the dry forest management and conservation managers and researchers for effective dry forest management. In the future, measures of variability, such as standard deviations and ranks, may be much more useful in describing, comparing forest communities (Jongman et al., 1995) and empirical data derived from landscape studies on species composition and abundance patterns are needed in order to test more complex concepts related to tropical plant communities, of which the metacommunity theory is an example (Chase, 2005).

\section{REFERENCES}

Adekunle, V.A.J., A.O. Olagoke, A.O. and S.O. Akinele. 2013. Tree species diversity and structure of a Nigerian strict nature reserve. Tropical Ecology. 54:275-289.

Armenteras, D., N. Rodriguez and J. Retana. 2009. Are conservation strategies effective in avoiding the deforestation of the Colombian Guyana shield? Biological Conservation. 42:1411-1419.

Ashton, M.S., N.V.L. Brokaw, R. Bunyavejchwin, G.B. Chuyong, L. Co, H.S. Dattaraja, S.J. Davies, S. Esufali, C.E.N. Ewango, R.B., Foster; N., Gunatilleke, S., Gunatilleke, T.H., Hart, C. Hern?ndez, S.P. Hubbell, A. Itoh, R. John, M. Kanzaki, D.S. Kenfack, Kiratiprayoon, J.V. LaFrankie, H-S. Lee, I. Liengola, J-R. Makana, N. Manokaran, M. Navarrete-Hern?ndez, T. Ohkugo, R. Pérez, N. Pongpattananurak, C. Samper, K. Sringernyuang, R. Sukumar, I-F. Fun, H.S. Sureh, S. Tan, D.W. Thomas, J.D. Thompson, M.I. Vallejo, G. VillaMunoz, R. Valencia, T. Yamakura and J.K. Zimmerman. 2004. Floristics and vegetation of the Forest Dynamics Plots, E.C. Losos and Leigh Jr. E.G (Eds.),Tropical Forest Diversity and Dynamism: Findings From a Large-Scale
Plot Network, University of Chicago Press., Chicago. pp. 90-102.

Attua, E.M. and O. Pabi. 2013. Tree species composition, richness and diversity in the northern forest-sananna ecotone of Ghana. Journal of Applied Biosciences. 69:5437-5448.

Baraloto, C., Q. Molto, S. Rabaud, B. Hérault, R. Valencia, L. Blanc, P.V.A. Fine and J. Thompson. 2013. Rapid simultaneous estimation of above ground biomass and tree diversity across Neotropical forests: a comparison of field inventory methods. Biotropica. 45:288-298.

Bawa, K.S., W.J. Kress and N.M. Nadkarni. 2004. Beyond paradise: meeting the challenges in tropical biology in the 21st century. Biotropica.36:276-284.

Chase, J.M. 2005. Towards a really unified theory for metacommunities. Functional Ecology.19: 182-186.

Evariste, F.F., N. Bernard-Aloys And T. Nole. 2010. The important of habit characteristics for tree diversity in the Mengame Gorilla Reserve (South Cameroun). International Journal of Biodiversity and Conservation. 2: 155-165.

Fisher, L., I. Moeliono and S. Wodicka. 1999. The Nusa Tenggara uplands, Indonesia: Multiple-site lessons in conflict management.Chapter 3, D. Buckles(edt.), Cultivating peace: Conflict and collaboration in natural resource management. International Development Research Centre and World Bank.

Hawkins, B.A., R. Field, H.V. Cornell, D.J. Currie, J-F. Guégan and D.M. Kaufman. 2003. Energy, water, and broad-scale geographic patterns of species richness. Ecology. 84: 3105-3117.

Hawkins, B.A., F.S. Albuquerque, M.B. Araujo, J. Beck and L.M. Bini. 2007. A global evaluation of metabolic theory as an explanation for terrestrial species richness gradients. Ecology. 88: 1877-1888.

Huang, W., V. Pohjonen, S. Johasson, M. Nashanda, M.I.L. Katigula and O. Luukkanen. 2003. Species diversity, forest structure and species composition in Tanzanian tropical forests. Forest Ecology and Management. 173: 111-124.

Ingram, J.C., T.P. Dawson and R.J. Whittaker. 2005. Mapping tropical forest structure in southeastern Madagascar using remote sensing and artificial neural networks. Remote Sensing of Environment, Vol. 94 No. 4: 491-507.

Jongman, R.H.G.,C.J.F. Ter Braak and O.F.R. Van Tongeren. 1995. Data analysis in community and landscape ecology. Cambridge University Press, Cambridge.

Kacholi, D.S. 2014. Analysis of Structure and Diversity of the Kilengwe Forest in the Morogoro Region, Tanzania. International Journal of Biodiversity. 1-8.

Karger, N., J. Kluge, H. Kr?mer, M. Lehnert and M. Kessler M. 2011. The effect of area on local and regional elevational patterns of species richness. Journal of Biogeography. 38:1177-1185. 
Koonkhunthod, N., K. Sakurai and S. Tanaka. 2007. Composition and diversity of woody regeneration in a 37year-old teak (Tectona grandis L.) plantation in Northern Thailand. Forest Ecology and Management. 247: 246254.

Mulyani, A., A. Priyono and F. Agus. 2013. Semiarid soils of Eastern Indonesia: Soil classification and land uses. Developments in soil classification, land use planning and policy implications: Innovative thinking of soil inventory for land use planning and management of land resources. Innovative Thinking of Soil Inventory for Land Use Planning and Management of Land Resources. Springer Dordrecht Heidelberg. New York. London.

Myers, N., R.A. Mittermeier, C.G. Mittermeier, G.A.B. da Fonseca and J. Kent. 2000. Biodiversity hotspots for conservation priorities. Nature. 403: 853-858.

Neumann, M. and F. Starlinger. 2001. The significance of different indices for stand structure and diversity in forests. Forest Ecology and Management. 145: 91-106.

Noss, R. 1990. Indicators for monitoring Biodiversity: A hierarchical approach. Conservation Biology.4: 355-364.

Orth, D. and M. G. Colette. 1996. Espèces dominantes et biodiversité: relation avec les conditions édaphiques et les pratiques agricoles pour les prairies des marais du cotentin. Ecologie, vol. 27, no. 3: 171-189.

Pardini, R., S.M. de Souza, R. Braga-Neto and J.P. Metzger. 2005. The role of forest structure, fragment size and corridors in maintaining small mammal abundance and diversity in an Atlantic forest landscape. Biological Conservation, Vol.124 No. 2: 253-266.

Pepe, B., K. Surata, F. Suhartono, M. Sipayung, A. Purwanto and W.S. Dvorak. 2004 Conservation status of natural populations of Eucalyptus urophylla in Indonesia and international efforts to protect dwindling gene pools. Forest Genetic Resources. 31: 62-64.

Pigot, A.L. and J.A. Tobias. 2013. Species interactions constrain geographic range expansion over evolutionary time. Ecology Letters. 16: 330-338.

Rennolls, K. and Y. Laumonier. 2000. Species diversity structure analysis at two sites in the tropical rain forest of Sumatra. Journal of Tropical Ecology. 16: 253-270.

Ricklefs, R.E. 2015. How tree species fill geographic and ecological space in eastern North America. Annals of Botany. 115: 949-959.
Robinson, A.H. and D. Supriadi. 1981. West Timor nature conservation areas: trip report and recommendations. United Nations Development Programme/Food and Agriculture Organization, Directorate of Nature Conservation, Bogor, Indonesia.

Sanders, N.J., J.P. Lessard, M.C. Fitzpatrick and R.R. Dunn.2007. Temperature, but not productivity or geometry, predicts elevational diversity gradients in ants across spatial grains. Global Ecology Biogeography. 16: 640-649.

Schwarz, P.A., T.J. Fahey and C.E. McCulloch. 2003. Factors controlling spatial variation of tree species abundance in a forested landscape. Ecology,Vol. 84 No. 7: 1862-1878.

Shannon, C.E. 1948. Mathematical theory of communication. Bell Syst. Tech. J. 27:379-423.

Sharma, C.M., S. Suyal, S. Gairola and S.K. Ghildiyal.2009. Species richness and diversity along an altitudinal gradient in moist temperate forest of Garhwal Himalaya. Journal of American Science. 5:119-128.

Silva-Flores, R., G. Pérez-Verdhn and C. Wehenkel. 2014. Patterns of Tree Species Diversity in Relation to Climatic Factors on the Sierra Madre Occidental, Mexico. PLoS ONE 9(8): e105034. doi:10.1371/journal.pone.0105034.

Singh, J.S.2002. The biodiversity crisis: a multifaceted review. Current Science. 82: 638-647.

Soerianegara, I. and A. Indrawan. 1982. Forest ecology of Indonesia. Departemen Manajemen Hutan, Fakultas Kehutanan, Institut Pertanian Bogor, Indonesia. (In Indonesia).

Sundarapandian, S.M. and P.S. Swamy. 2000. Forest ecosystem structure and composition along an altitudinal gradient in the Western Ghats, South India. Journal Tropical Forest Science. 12: 104-123.

Trichon, V. 1997. Hétérogénéité spatiale d'une forêt tropicale humide de Sumatra: effet de la topographie sur la structure floristique. Annales des Sciences Forestières, INRA/EDP Sciences, vol. 54, no. 5: 431-446.

Wagner, C.E., L.J. Harmon and O. Seehausen. 2014. Cichlid species-area relationships are shaped by adaptive radiations that scale with area. Ecology Letters.17:583592. 